\title{
CLASSIFICATION AND DEVELOPMENT OF BEDROCK RESOURCES IN FINLAND
}

\author{
HEIKKI NIINI
}

\begin{abstract}
NIINI, HEIKKI, 1986: Classification and development of bedrock resources in Finland. Bull. Geol. Soc. Finland 58, Part 1, 335-350.

On the basis of an analysis of the present utilization of the bedrock in Finland, the bedrock resources have been classified into five groups that differ in nature and to some extent conflict with one another: (1) mineral resources, (2) bedrock groundwater, (3) underground space, (4) base for construction, and (5) rock-environment resources. The meaning, abundance, and economic significance of each group are discussed. The mineral resources are regarded as economically by far the most important bedrock resource in Finland. An analysis of the economic nature and the development of the mineral resources shows that in spite of continuous mining the abundance of known mineral resources will continue to increase for years to come.
\end{abstract}

Key words: mineral resources, rock construction, underground space, rock environment, ore classification, geological assurance, economic geology, bedrock, Finland.

Heikki Niini: Helsinki University of Technology, Laboratory of Economic Geology, Vuorimiehentie 2 A, SF-02150 Espoo.

\section{Introduction}

Since prehistoric times, when rock caves were used as dwellings, man has been utilizing the bedrock in many ways. Even man's early history is divided into main periods according to the material he had learned to exploit from the bedrock: the Stone, Bronze, and Iron Ages.

Nowadays, the diversity of ways in which the bedrock is used has increased rapidly and different interests may even be in or come into conflict with one another. Therefore, in order to control and treat the bedrock as a utilizable resource correctly, the various methods and targets of the utilization of the bedrock must be continuously studied and analysed. In every case the bedrock resource, as a concept, is a function of the human wishes and expectations directed at the bedrock.

\section{Fundamental goals of the use of the bedrock}

Human activities, or interests, regarding the bedrock are numerous and variable in nature, just as human interests are in general. An attempt has been made in this paper to list the main goals or targets of bedrock utilization by different human interests (Table 1) in terms of present-day Finnish conditions. The division of interests into 
ten groups is naturally arbitrary. The targets, five in number, are dealt with in the following.

\section{Mineral material (ore)}

The exploitation of solid mineral material from the bedrock is the main target of the mining industry. It includes the exploitation of ordinary metalliferous ore minerals and mineral materials for different kinds of chemical and/or physical industrial processing. In Finland, the mineral materials (here all called ores) can be divided into three main groups and these into subgroups as follows:

1. Mineral ores, i.e. rocks with valuable or target minerals:

- metalliferous minerals

- industrial minerals

- energy minerals

- precious minerals (gemstones)

2. Rocks for dimension stones (dimension-stone ores); i.e. raw material for

- building stones

- monument stones

- (other) useful stones

3. Rock-aggregate ores; i.e. raw material for

- blasted rock

- crushed rock

- ground rock

- screening products.
The m i n e r a 1 o r e s are rocks containing valuable minerals that are normally physically separated from other minerals (the gangue minerals) to form mineral concentrates. The gangue minerals of an ore - often the bulk of the rock - form more or less useless refuse or tailings. According to common usage in the Finnish mining industry, the economic term »ore» is no longer restricted merely to rocks containing metalliferous (or opaque) minerals. The valuable minerals of the ores may thus consist of

- metalliferous minerals (the former »ore minerals»), the raw material for the metallurgical industry,

- industrial minerals (rocks), forming the raw material for many types of industry, e.g. the chemical, glass, ceramics, constructionmaterial, and paper industries,

- energy minerals such as graphite - or coal (though not produced in Finland) - and pyrite and other iron sulphides that in combustion produce thermal energy; this group also includes the uranium- and thoriumbearing minerals that can be used as raw material for nuclear energy,

- precious minerals, which are produced in minute quantities for jewellery, e.g. the plagioclase (labradorite or spectrolite) mined at Ylämaa, SE Finland.

Table 1. Main target and interest groups within the utilization of bedrock in Finland. Key: 1 The type of resource forms an essential target of the activity, + target secondary, 0 minor effect on the type of resource, - adverse effect on the type of resource.

\begin{tabular}{|c|c|c|c|c|c|}
\hline \multirow[t]{2}{*}{ Interest group } & \multicolumn{5}{|c|}{ Type of resource or target of the use of bedrock } \\
\hline & Minerals & $\begin{array}{c}\text { Ground- } \\
\text { water }\end{array}$ & $\begin{array}{l}\text { Under- } \\
\text { ground } \\
\text { space }\end{array}$ & $\begin{array}{l}\text { Base for } \\
\text { construc- } \\
\text { tion }\end{array}$ & $\begin{array}{c}\text { Rock } \\
\text { environ- } \\
\text { ment }\end{array}$ \\
\hline Minerals industry $\ldots .$. & 1 & - & + & - & - \\
\hline Construction activity $\ldots \ldots \ldots \ldots \ldots \ldots$ & 1 & $0,-$ & 1 & 1 & $0,-$ \\
\hline Chemical industries $\ldots \ldots \ldots \ldots \ldots \ldots \ldots \ldots$ & 1 &,+- & 0,1 & + & 0 \\
\hline Traffic (e.g. roads, railways, canals, tunnels) .. & 0 & - & 0,1 & $1,-$ & $0,-$ \\
\hline 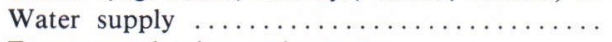 & 0 & 1 & + & + & 1 \\
\hline Energy production and storage $\ldots \ldots \ldots \ldots \ldots$ & $0,+$ &,- 1 & 0,1 & 1 & 0,1 \\
\hline Waste disposal and environmental protection .. & - &,- 1 & + &,+- & 1 \\
\hline Recreation (e.g. sport halls) ............ & 0 & 0 & + & + & 0 \\
\hline Community (city) planning $\ldots \ldots \ldots \ldots \ldots$ & + & + & + & 1 & + \\
\hline Defence (e.g. shelters) . . . . . . . . . . . & + & 0 & 1 & 1 & 0 \\
\hline
\end{tabular}


The dimension-stone ores are rocks that are processed and used physically as solid pieces with definite dimensions. The qualifications as to the dimensions and other properties depend, on the one hand, on the purpose of utilization and, on the other, on the mineralogical composition and texture of the rock. According to the purpose of utilization the dimension stones comprise

- building stones (consisting mostly of homogeneous intrusive rocks or of marble), including stones used massively as thick supporting structures in foundations, bridges, and walls, as thin sheet facings in buildings, and as pavement stones in streets,

- monument stones, consisting of decorative rocks suitable for individually manufactured gravestones and statues,

- other useful stones consisting of various rocks suitable as raw material for many purposes, e.g. heavy rollers of paper machines (granite), heat-storing and -isolating sheets in ovens and fireplaces (soapstone), sharpening and polishing stones (phyllite, quartzite), and ash trays (marble). One special stone product typical of Finland is the roughly fist-size rock pieces used in sauna stoves. Since these must be mechanically and chemically heat-resistant, they usually consist of pyroxene-, hornblende-, or olivine-rich, sulphide-free mafic rocks.

T h e r o c k - a g g r e g a t e o r e s are rocks that are used as aggregates composed of loose rock or mineral particles more or less irregular in shape. This group includes blasted rock (as such) with large sharp-edged blocks, crushed rock in which the original large blocks have been reduced in particle size, and other kinds of comminuted (ground) and/or screened rock products. These rock materials are used mostly for earth, road, and railway construction or as essential constituents of concrete. The various gradation specifications are met by screening. The mining of rock-aggregate ores from the bedrock in Finland is increasingly replacing the exploitation of loose Quaternary mineral formations (sediments such as gravel, sand, and till) for the same purposes.

The exploitation of ores, i.e. solid mineral raw materials, only takes place here and there (see Figs $1 \mathrm{~A}$ and $1 \mathrm{C}$ ), but where suitable rocks occur it must be taken into account in community planning, at least as a potential form of activity.

As certain valuable minerals are crucial for the manufacture of strategic products but are unevenly distributed among different countries, they are of special interest to the armed forces.

\section{Groundwater}

Extraction of liquid or gas from the pores of the bedrock includes such world-wide, important activities as the pumping of petroleum and natural gas for the chemical industry and energy production. In Finland, however, where the Precambrian bedrock lacks oil- and gas-bearing formations, the only essential non-solid material in the bedrock is groundwater. As the pore volume proper of Finnish rocks is diminutive, the volume in which the groundwater occurs is formed by the various mechanical discontinuities of the bedrock: the fractures, joints, fissures, cracks whatever they are called. In these, the groundwater is moving slowly but continuously from higher areas with a higher water table and higher hydraulic pressure to lower areas where it either (in hillside springs) flows back to the surface or discharges directly to the bottom of rivers, lakes, or the sea.

The groundwater in the bedrock constitutes one of the primary sources of municipal and industrial water supply. To ensure the undisturbed extraction of groundwater a limited body of bedrock around the pumping well must be protected from other kinds of use. The types of bedrock utilization in which the rock is mined or contaminated prevent or at least hamper the utilization of the groundwater resource of the bedrock.

Most Finnish water supply needs are met by 

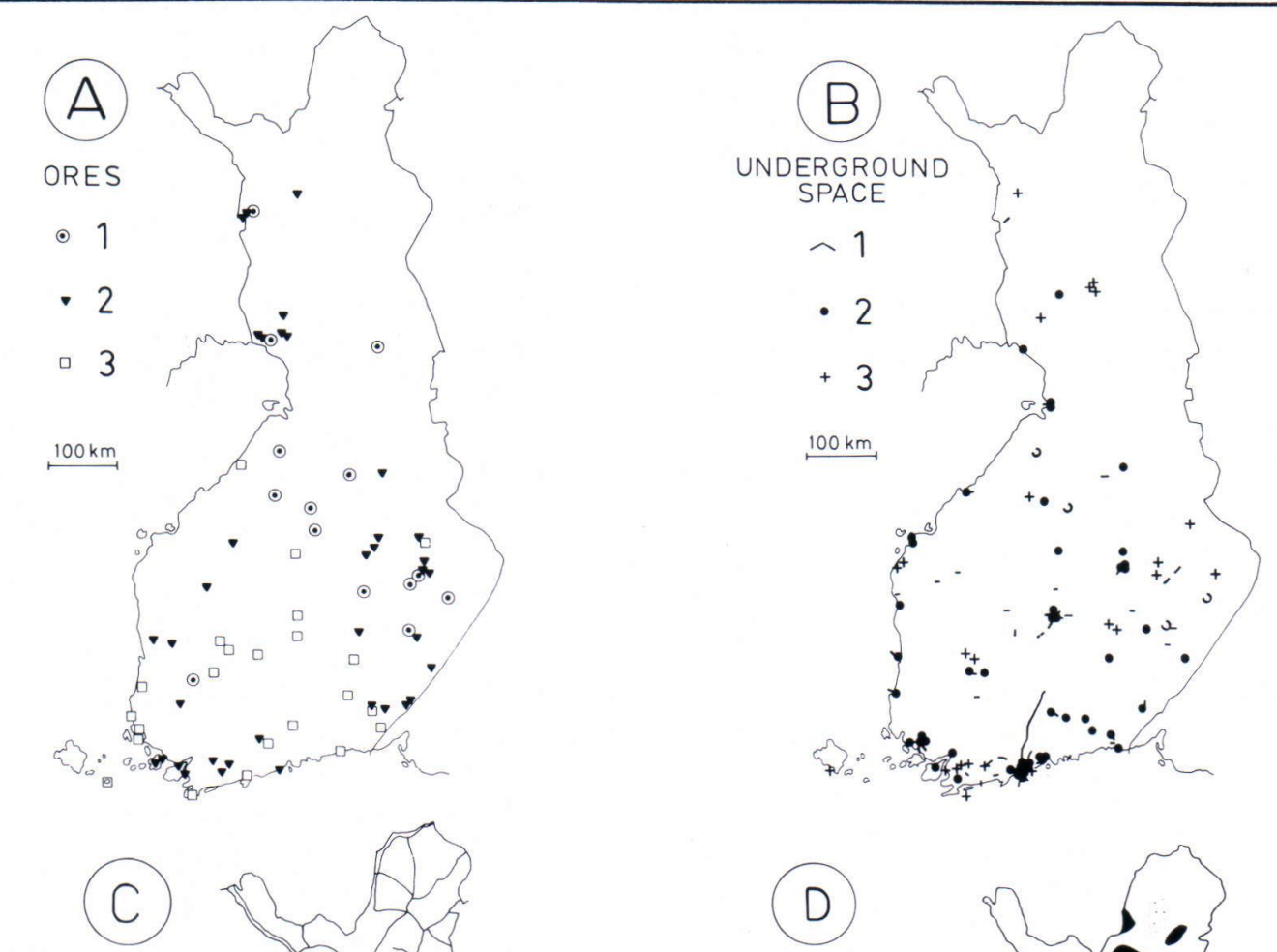

BASE FOR CONSTRUCTION

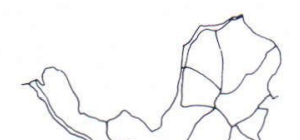

\section{N}
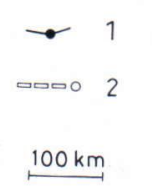

-
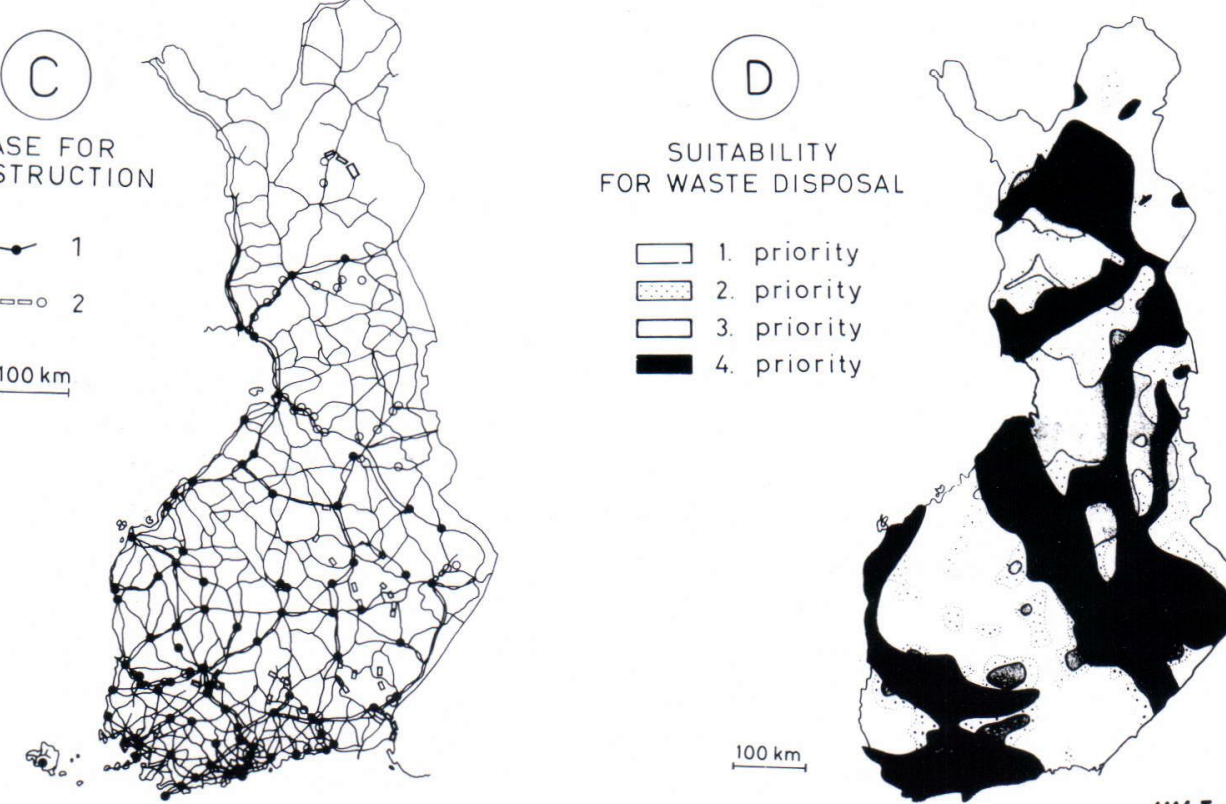

FOR WASTE DISPOSAL

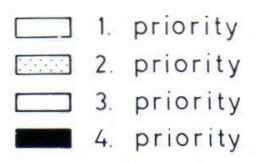

ponom,

,


surface waters and groundwater from the coarsegrained, porous Quaternary sediments, but an increasing proportion of the household water supply of sparsely populated communities is met by pumping from deep wells drilled into the bedrock (Rönkä 1983). Finland does not (yet) have a national data register of rock wells, but their number can be estimated to exceed 100,000 in the near future. They are distributed rather evenly over the southern half of the country.

In contrast to petroleum and natural gas, the groundwater in the bedrock is a renewable resource. The amount of water regularly extractable is determined by the regular annual input, that is, the groundwater recharge from the precipitation in a certain catchment or intake area. Naturally, the entire groundwater storage of a certain rock body can also be temporarily exploited.

\section{Underground space}

From the point of view of underground rock construction, the bedrock is regarded as a natural, rigid and permanent construction material used in situ. To create underground space the rock material must be blasted and removed from rock openings in such a manner as to ensure that the rock roofs and walls retain their strength as far as possible. In a broad sense, »bedrock resource» in this case consists of bedrock formations (with their adequate surroundings) suitable for underground construction. In a strict sense, once an underground cavern has been excavated, the rock removed forms waste and no longer belongs to the space resource, but is available for use as another kind of resource: rock aggregate.

The qualifications of a rock mass for different types of underground construction depend basically on (1) the purpose of the construction, (2) the lay-out of the openings, (3) the methods of rock treatment, and (4) general economic and social conditions varying in time. Overall evaluation of any large part of the bedrock as a resource for underground space is therefore very difficult.
The purposes of the use of underground space, which essentially determine a geological formation as a kind of underground-space resource, are various. In Finland, three basic types of underground caverns have been made and used since the early decades of the century and still are frequently constructed (see Fig. 1 B):

1. Long openings for transport, consisting of railway, road, subway, water-conveyance, sewage, and cable tunnels as well as mine drifts and shafts.

2. Wide openings for holding permanently or temporarily people, materials, processes, or activities, such as shelters, storage facilities (e.g. oil, water, sand, salt, and cars), workings, power stations, and recreation facilities; even one art gallery (at Punkaharju, SE Finland) now belongs to this category.

3. Empty stopes left after the exploitation of mineral resources. These openings are an unavoidable by-product of all underground mining. As empty space in the bedrock weakens the bedrock and thus tends to damage both the ore mining itself and the environment the stopes are usually partly filled with waste rock. The stopes are then used as stores and thus reduce the amount of surface land needed for dumps. Similarly, any underground space that is no longer used for its original purpose should be considered as an underground-space resource for other purposes.

When considering the development of the use of the bedrock for underground construction, we must take into account the continuously growing need for space on the surface and the increasing requirements of environmental protection applied to many surficial activities. Hence the economic significance of the bedrock as an underground-space resource is being enhanced.

\section{Base for construction}

The use of the bedrock as the base or foundation for surficial buildings or constructions is twofold. 
First, because of its generally good strength properties, the bedrock is used as the s o li d g round for supporting heavy c o n s t r u c t i o n s, e.g. high buildings, pillars, towers and masts, concrete dams, and large bridges. Finland does not belong to the seismic zones of the globe, where earthquakes make the bedrock a dangerous direct foundation for such constructions and they have to be built using special techniques. The bedrock in Finland is generally suitable as such; only the distinct weakness zones - fracture and fault lines and weathered sites - are not sufficiently firm and rigid as supporting ground for heavy constructions. In order to maintain the good strength properties of a rock body used as a base for construction, no rock may be blasted in (or removed for other purposes from) that body. This type of bedrock resource may thus conflict with the concepts of the mineral resource and underground-space resource.

Second, because of its general morphology, the bedrock offers a s u t a ble bot to m t o p o g r a p h y (mostly sufficiently even) for certain constructions of large areal extent, e.g. railways, roads and streets, natural waterways and dug canals, and artificial water basins. The bedrock topography also has advantages for water power generation, the original height difference between two areas causing the essential hydraulic head. In all these cases the suitable bedrock topography itself can be regarded as a resource. Where suitable topography does not exist, either expensive blasting is required or the whole project may be jeopardized. Because the inner properties of the bedrock do not directly affect the utilization of the bedrock topography, this type of bedrock resource seldom conflicts with other types of bedrock resource.

\section{Rock environment}

The bedrock may offer a suitable matrix or environment for certain phenomena that man is capable of utilizing. In the present context the two particular targets of bedrock utilization are thermal energy and disposal of radioactive waste. (In a strict sense, the circulation of groundwater in the bedrock should also be included in the same group of phenomena; owing to its universality, the subject has been dealt with separately.)

The bedrock may be used as either a source of or a storage matrix for $\mathrm{th}$ e $\mathrm{r} \mathrm{m}$ a $\mathrm{l}$ e $\mathrm{n}$ e $\mathrm{r} \mathrm{g}$. The bedrock of Finland is not a favourable source of thermal energy because of its very low temperature gradient and heat flow. According to measurements from 15 localities in the Precambrian basement of the southern half of Finland, the temperature gradient is $9-14 \mathrm{~K} / \mathrm{km}$ and the heat flow $22-38 \mathrm{~mW} / \mathrm{m}^{2}$ (Järvimäki and Puranen 1979). As for the storage of thermal energy or the retention of heat, however, projects can be planned permitting economic utilization of the thermal properties of the bedrock. The first major heat storage project to do so in Finland - and for which an opening of $1500 \mathrm{~m}^{3}$ for circulating water was excavated in the bedrock - was completed at Kerava, a town near Helsinki (Ritola 1983). The effective storage capacity of the system is $250 \mathrm{MWh}$.

The construction of four nuclear power plants with a total capacity of over $2300 \mathrm{MW}_{\mathrm{e}}$ has made the use of the Finnish bedrock as a site for d u m p i n g a d i o a c t i v e wa s t e into an economically important issue with social and political implications. This delicate problem, which has aroused the passions of the general public as well as of politicians, will not be discussed here; only its significance to the concept of bedrock resources will be touched on.

The disposal of radioactive waste in a certain formation of the bedrock will presumably prevent that site and its underground environment from being used for other purposes for exceptionally long periods. When choosing the site or sites for bedrock repositories of high-level radioactive waste, it is therefore important to study carefully what kind of utilization of other bedrock resources must be sacrified in a certain area around the repository. Because of the nature of radioactive decay, the time in question is mea- 
sured in hundreds of thousands of years; this is said to be unique, i.e. longer by far than the periods for which any other human plans whatsoever have been or are made.

On the other hand, what is really essential in this context is not the period the plans are made for but the length of the period the consequences will be felt. And there are certainly a number of human activities the consequences of which will be felt for even longer periods - in fact for ever. The exhausting of any unrenewable resource, e.g. a mineral deposit, imposes a certain restriction to all future generations. And how far-reaching in time are the unforeseen consequences of, say, the immense burning of coal affecting the future aumosphere, and the nomadism eroding and devastating huge areas in undeveloped countries and elsewhere? Therefore, it can be assumed that the disposal of radioactive waste in a very common rock material - say, granite or granodiorite in Finland - cannot really squander other possible future bedrock resources. And even if it were to, the incident would by no means be unique.

Be that as it may, considering the large area covered by Precambrian rocks in Finland, the disposal of radioactive waste is not such a great problem as in countries with a denser population and less tranquil geological conditions. Therefore, the bedrock of Finland offers a special type of economic resource (see Fig. 1D) as a potential environment for the disposal of hazardous wastes. The utilization of this bedrock resource, even from the international point of view, should be examined without any of the fanaticism that has prevented many countries from finding final solutions to the problem so far. Fortunately, the number of the repositories for the terminal disposal of high-level radioactive waste will be limited (in Finland most probably only one). Therefore, the total influence of the utilization of this particular bedrock resource on the other resource groups is minimal - in area little more than a dot on the map.

\section{The concept of bedrock resources}

According to the five fundamental goals of the use of the bedrock discussed above, the resources it offers to man can be divided into five corresponding resource types differing in nature. Another alternative is to consider the concept »resource» in such a way that any limited body of bedrock represents but one total resource. In that case, however, this resource must be characterized by the five factors discussed. The same result is therefore reached with either way of consideration.

Because the concept »bedrock resource» is thus affected or characterized by several different and sometimes mutually conflicting interests, the utilization of the bedrock resources as economically as possible always requires the determination and comparison of the possible benefits and losses for all possible interests. The optimum utilization of the bedrock resources also necessarily comprises a mutual long-term adjustment of the different targets.

Generally, and in most of the individual cases, however, the different types of bedrock resources are economically very unequal. The resources connected with the rock environment, the base for construction, and the groundwater are still relatively less important than those characterized by mineral materials and underground space. During the 1970s the volume of rock excavated annually in Finland for ground engineering roughly rose to the same level as that excavated by the mining industry. In the years 1978-1980, however, the volume of rock excavated from Finnish mines exceeded $60 \%$ of the total volume of rock excavated annually in Finland (about 13 mill. $\mathrm{m}^{3}$; Virtanen 1982). When comparing the two spheres of interest, we must remember that only a small fraction of the volume of rock excavated for construction (ground engineering) originates from underground spaces.

The cost of the volume of mining for underground construction may roughly characterize the economic value of the underground-space 
resource. But as to the utilization of valuable minerals - the target of the mining industry the cost of its volume of mining is only a startingpoint in a long series of industrial processes: mining-ore comminution-mineral separationwaste removal-gangue treatment-concentrate transport-concentrate smelting - slag treatment, and so on, which the value of the target minerals must cover. The total value of the utilization of the mineral resource in Finland is thus many times that of the underground-space resource.

As this analysis shows, economically by far the most important bedrock resources in Finland are still the mineral materials, or the ores.

\section{Ore resources}

\section{The changing concept}

Several definitions have been used for the term »ore». It used to be common to use the term to refer to metalliferous minerals alone, i.e. to geological occurrences with a natural metal concentration. Nowadays the term is used in a wider sense. Most authorities are agreed upon one crucial prerequisite for use of the term: the concentration must be sufficiently rich and large to permit economic utilization either at present or in the near future. Therefore, as already mentioned, the Finnish mining industry generally uses the term »ore» to denote a rock with any valuable mineral that can be mined economically, i.e. with profit. As such a concept is needed principally for the planning and realization of the first stage of exploitation, in which the valuable rock should be separated from the valueless, it is most convenient to expand the term to eliminate the arbitrary effect of the final target of the processing of the rock. A recent definition for this modern concept of »ore» is thus: any rock economically minable for its own properties (not to create underground space). This definition purposefully includes not only the ores of individual valuable minerals but also the construction materials: the rocks usable for dimension stones and for rock aggregates.

Owing to the economic or profit element in the concept, the amount and quality of any one ore resource is continuously subject to change. The different factors regulating these changes can be divided into three categories: (1) those decreasing the ore resources, (2) those capable of both decreasing and increasing the economic ore resources (and, in fact, alternating rather frequently), (3) those increasing the economic ore resources.

1. One important factor that systematically decreases the economic ore resources is mining itself: any orebody can be mined only once and at the same time the remaining resources are decreased in corresponding proportions. Another factor, albeit indirect, that tends to reduce the usable ores is generated by the growing demands of environmental protection: the rising costs require a richer or better ore (with less waste).

2. Factors alternately increasing and decreasing the economic ore resources belong to the complex category of economic-social-political conditions - such as price trends of the mineral commodity -, which cannot be treated here in detail. As to the metalliferous ores, one such factor determined by the mine organization itself is the capacity, or annual production, of the mine. The capacity of a mine is often raised in order to reduce the pay-back period and hence the interest costs. If this operation is successful it naturally allows a reduction in the cut-off grade, or the minimum tenor, of the ore. In most ore types this automatically causes an increase in the ore resources; only orebodies with very sharp contacts may remain unchanged. - However, the increase in the capacity may sometimes lead to an unexpected need for extra investment or extra running costs. If that happens, intensified production may not shorten the pay-back period but merely the life-time of the mine. The cut-off will then 
tend to rise and, correspondingly, the economic ore resources to decrease.

According to Tyni (1981), changes in world-market prices during the 10-year period 1970-1980 have caused the cut-off grade of the $\mathrm{Zn}, \mathrm{Pb}, \mathrm{Ni}$, and $\mathrm{W}$ ores to increase by $30-50 \%$ and that of the $\mathrm{Cu}$ ores by over $100 \%$, whereas the cut-off of, say, the $\mathrm{Sn}$ and Mo ores has diminished to $2 / 3$ and that of the $\mathrm{Ag}, \mathrm{Co}$, and $\mathrm{Au}$ ores to $1 / 3-1 / 5$ of the former cut-off limits.

3. Several factors may increase the economic ore resources:

Exh a us ting of richer ores. In the long term, both the average and the cutoff grades of the remaining exploitable material are necessarily decreasing; a poorer and hence more common rock then becomes an ore.

E a sie r a c e s s to d e e p e r le ve l s. Economic resources commonly grow simply because of improvements to the information on ore formation gained as mining has gradually reached deeper levels. Some of the uncertain ore concentrations then become economic.

Existence of necessary fac i 1 i t i e s. After the amortization of investment by rapid exploitation of the richest parts of the ore, the economic requirements may be relaxed to permit mining of poorer and hence larger orebodies of the occurrence or in the vicinity.

D e v e lo p m e n t of t e ch nolog y. Many known mineral concentrations (ore showings) are either large but too poor or rich but too small to make mining feasible at the present level of technical ability. The threshold may be overstepped by the introduction of a new technical process or application. On several occasions active technical development work of this nature has led to the production of a new mineral commodity. To take an example, it was long uncertain if the large but low-grade concentration of chromite at Kemi in northern Finland actually formed an economic ore until a suitable new process was developed for it.

A c t ive ore exploration. The most important factor increasing ore resources is, however, none other than exploration for ores. In geological terms, it is clear that, in Finland at least, only a fraction of the total potential ore resources is known to date. The deeper ore concentrations in particular are still waiting for their discoverers.

\section{Ore classifications}

In ore geology, the metalliferous ores are basically classified by origin and geological history. This classification, although rather arbitrary in some respects, has long been successfully applied to ore exploration - and will certainly continue to be so. But the exploration of any ore resources necessarily also requires other types of ore classification that geologists should bear in mind. In fact, different practical targets need different classifications based on different criteria, e.g. those depending in one way or another on geological conditions such as

- the geographic and the general geological location (e.g. conditions concerning transport, energy, employees, and competing options) of the ore deposits (this factor is naturally important for those deciding about the basic investment),

- the behaviour of the minerals in technical processing, the final uses, and the markets of the products aimed at (important for project managers),

- the geometrical parameters (form and attitude) of the orebodies (important for the designers of the mine structure),

- the mining-technical conditions (the rockmechanical structure and strength) of the orebodies and the country rocks (important for the managers of the mining operations),

- the species, tenor, and atomic structure of the target minerals of the metalliferous ore deposits (important for ore dressers), 
- the assurance of the geological information available about the ore deposits (important for investors and explorers).

This report does not attempt to deal with all these classifications but rather with the latter two, which are intimately related to geological factors.

T a r g e t minerals. When it comes to mineral ores, the valuable or target minerals of the ore must always constitute the principal criterion of ore classification for the ordinary miner, because - by definition - it is the target mineral that forms the final product of the mine, the concentrate. The quality, or tenor, of the ore is however often indicated simply by the content or grade of certain valuable elements (or metals) in the ore. This simplification is often misleading, because in reality the value of the ore is dependent on the (amount of) certain elements contained in the target minerals alone and not on the bulk content of any particular element. The grade control of an ore should therefore always be twofold: (1) control of the tenor and type of occurrence of each target mineral in the ore and (2) control of the variation in the chemical composition or other crucial property of each target mineral.

As to metalliferous ores in particular, many target minerals vary in composition, and it is precisely this variation that is crucial for concentrates, the final products of the mine: the mechanical process of ore dressing cannot augment the content of a valuable element in the concentrate so that it exceeds its content in the target mineral. Therefore, the purpose of a practical ore classification would be met if the composition of the target minerals of the ores were indicated by a mineral-chemical formula showing, at least, the possible diadochy between certain elements and, preferably, the abundance ratios of the most important diadochic elements.

In Finland, a classification of current metalliferous ores according to main target minerals contains a mere eight minerals (Table 2). Certain other metalliferous minerals were mined earlier during short periods; these include the tin minerals cassiterite $\left(\mathrm{SnO}_{2}\right)$ and stannite $\left(\mathrm{Cu}_{2} \mathrm{FeSnS}_{4}\right)$ from Pitkäranta in Karelia (now in the USSR), molybdenite $\left(\mathrm{MoS}_{2}\right)$ from Mätäsvaara, scheelite $\left(\mathrm{CaWO}_{4}\right)$ from Ylöjärvi, native gold $(\mathrm{Au})$ from Haveri, pitchblende ((U,Th) $\left.\mathrm{O}_{2-2,67}\right)$ from Paukkajanvaara, pyrrhotite $\left(\mathrm{Fe}_{1-x} \mathrm{~S}\right)$ from many mines, e.g. Luikonlahti, spessartite $\left(\mathrm{Mn}, \mathrm{Fe}^{2+}, \mathrm{Ca}\right)_{3}$ $\left(\mathrm{Al}, \mathrm{Fe}^{3+}\right)_{2}\left(\mathrm{SiO}_{4}\right)_{3}$ from Jussarö, and lanthanoid minerals from Korsnäs.

Once the target minerals have been chosen as

Table 2. The main target minerals (or mineral concentrates) of the Finnish mines that exploited metalliferous ores in 1983.

\begin{tabular}{|c|c|c|c|c|c|c|c|c|c|c|c|c|c|c|}
\hline \multirow[t]{2}{*}{ Mineral } & \multicolumn{14}{|c|}{ Mine } \\
\hline & $\underset{\beth}{\bar{D}}$ & 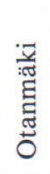 & 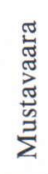 & 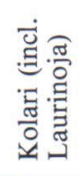 & 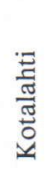 & $\underset{\Xi}{\Xi}$ & 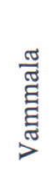 & 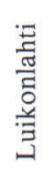 & $\begin{array}{l}0 \\
0 \\
0 \\
3\end{array}$ & 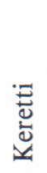 & 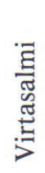 & 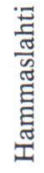 & 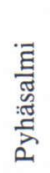 & 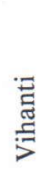 \\
\hline Chromite $\left(\mathrm{Fe}^{2+}, \mathrm{Mg}\right)\left(\mathrm{Cr}, \mathrm{Fe}^{3+}\right)_{2} \mathrm{O}_{4} \ldots \ldots$ & $\times$ & & & & & & & & & & & & & \\
\hline Magnetite $\mathrm{Fe}^{2+}\left(\mathrm{Fe}^{3+}, \mathrm{V}\right)_{2} \mathrm{O}_{4} \ldots \ldots \ldots \ldots$ & & $\times$ & $x$ & & & & & & & & & & & \\
\hline $\mathrm{Fe}^{2}+\mathrm{Fe}^{3+}{ }_{2} \mathrm{O}_{4} \quad \ldots \ldots \ldots \ldots \ldots$ & & & & $x$ & & & & & & & & & & \\
\hline Ilmenite $(\mathrm{Fe}, \mathrm{Mn}, \mathrm{Mg}) \mathrm{TiO}_{3} \ldots \ldots \ldots$ & & $\times$ & & & & & & & & & & & & \\
\hline $\begin{aligned} \text { Pentlandite } & (\mathrm{Ni}, \mathrm{Fe})_{9} \mathrm{~S}_{8} \ldots \ldots \ldots \ldots \ldots \ldots \\
& (\mathrm{Co}, \mathrm{Fe}, \mathrm{Ni})_{9} \mathrm{~S}_{8} \ldots \ldots \ldots \ldots \ldots\end{aligned}$ & & & & & $x$ & $x$ & $x$ & $x$ & $\times$ & & & & & \\
\hline Chalcopyrite $\mathrm{CuFeS}_{2} \ldots \ldots \ldots \ldots$ & & & & $\times$ & $x$ & $x$ & $x$ & $x$ & $x$ & $\times$ & $\times$ & $\times$ & $x$ & $x$ \\
\hline $\begin{array}{c}\text { Pyrite }(\mathrm{Fe}, \mathrm{Co}) \mathrm{S}_{2} \ldots \ldots \ldots \ldots \ldots \ldots \ldots \ldots \ldots \\
\mathrm{FeS}_{2} \quad \ldots \ldots \ldots \ldots \ldots \ldots\end{array}$ & & & & & & & & & & $\times$ & & & $\times$ & \\
\hline Sphalerite $(\mathrm{Zn}, \mathrm{Fe}) \mathrm{S} \ldots \ldots \ldots \ldots \ldots$ & & & & & & & & $x$ & $x$ & $x$ & & $x$ & $x$ & $x$ \\
\hline Galena $\quad \mathrm{PbS} \ldots \ldots \ldots \ldots \ldots \ldots$ & & & & & & & & & & & & & & $x$ \\
\hline
\end{tabular}


the primary criterion of ore classification, many possibilities remain from which to choose the secondary criteria. However, if the number of ore deposits to be classified is limited (cf. Table 2), the basic criterion alone may be sufficient. The different combinations as such of the target minerals form a natural division of the ore types. Such a clear division of ore deposits can be applied to ore showings, too, and as shown by Mikkola and Niini (1968), it does not essentially differ from a purely genetical ore classification.

\section{Areal ore resources}

In the above primary ore-classification criteria the last on the list is the assurance of the geological information available. As with all the other criteria mentioned, the subject is an individual deposit and the information on it is presumed to be reliable, i.e. established by adequate studies. But should the subject be the bulk of many or all the deposits in an area, the information can be neither uniform nor comprehensive, and so the reliability, or assurance, of the information must be taken into account.

It is important that the owners and directors of the mining industry, political economists, and politicians have circumstantial information about the total ore resources of a company, an area, or a country in order to make long-range plans for exploitation. Because decision-makers avoid unnecessary risks, their decisions must be based on information as reliable as possible. The information available should therefore be classified according to the level of assurance. As the ore resources consist of geological material, the most important basis of the classification is the assurance of the geological information on the possible ore formation.

Over the years, several different classifications of areal ore resources according to the level of geological assurance have been devised in different countries (see e.g. Banfield and Havard 1975, USBM-USGS 1976, Fettweis 1981, Gocht 1983). To mitigate the confusion caused by the inconsistencies in resource terminology, the United Nations created and recommended a new letter-number system for mineral-resource classification (UN 1979). This classification is meant primarily for mineral ores, but in principle it can be applied to dimension-stone and rock-aggregate ores as well. The classification comprises three basic resource categories characterized according to the level of geological assurance: R-1 (reliable estimate of a known deposit), R-2 (preliminary estimate of a newly discovered deposit or extension of a known deposit), and R-3 (tentative estimate of an undiscovered deposit). All these categories represent deposits that might be of economic interest in the next 20 or 30 years.

Only in the first category (R-1) is the geological information sufficient for the planning of mining activities (estimation error less than $50 \%$ ). This category is divided into three subcategories according to the economic interest: R-1-E (economically exploitable resources), R-1-M (marginally economic resources), and $\mathrm{R}-1-\mathrm{S}$ (subeconomic resources).

The second category (R-2) is based largely on broad geological knowledge supported by some measurements (estimation error over $50 \%$ ). This category consists of two subcategories: R-2-E (economically exploitable resources) and R-2-S (subeconomic resources).

The undiscovered R-3 resources (earlier speculative or potential resources) are thought to exist on the basis of geological extrapolation, geophysical or geochemical indications, or statistical analogy.

All the categories mentioned are called resources (not reserves) and geological material lower in economic potential than a resource is referred to as an »occurrence». The capital » $\mathrm{R} »$ in all the symbols mentioned denotes in-situ quantities; the corresponding recoverable quantities of the resources would be indicated by $» r »$.

This U.N. classification can be regarded as a global compromise or a kind of summary of the various mineral-resource classifications commonly used in the past. As such, it should be preferred 
to the diversity of national systems. This classification is two-dimensional, the two dimensions or variables on which it is based being geological assurance and economic interest. In the following a closer look is taken at economic interest.

E c o n o mi c i n t e rest. As already explained while analysing the concept »ore», economic interest is a complex factor. It encompasses two main components. First, the deposit must meet the requirements referring to specific natural geological features, i.e. the grade and quantity of the target minerals. Second, the exploiter must have good command of the various technical and social factors affecting the feasibility of the exploitation of the deposit. Simply by incorporating one additional dimension, the division of economic interest into these two components can be added to the U.N. resource classification without changing it in any way. This new dimension is formed by either of the components of economic interest (Fig. 2). The classification is now three-dimensional and can be represented visually by a cube. Two surfaces of the cube are like the two-dimensional U.N. classification and one (the upper) surface indicates the division of economic interest into two components.

Every geological occurrence (or potential mineral resource) first appears in this cubic diagram somewhere at the bottom of the box »unknown». As the geological information on the occurrence is augmented by ore exploration, the deposit wanders upwards in the system until it finally reaches one of the uppermost boxes. Geological assurance is then at its maximum. This means that the grade and quantity of the deposit are known accurately and cannot be (fundamentally) changed by man. But the technical and social feasibility of the deposit is dependent on human factors, particularly on the development work. This component of economic interest can therefore shift a deposit that had already reached the upper level from one box to another, to a better one, e.g. from R-1-M to R-1-E. This is, in fact,

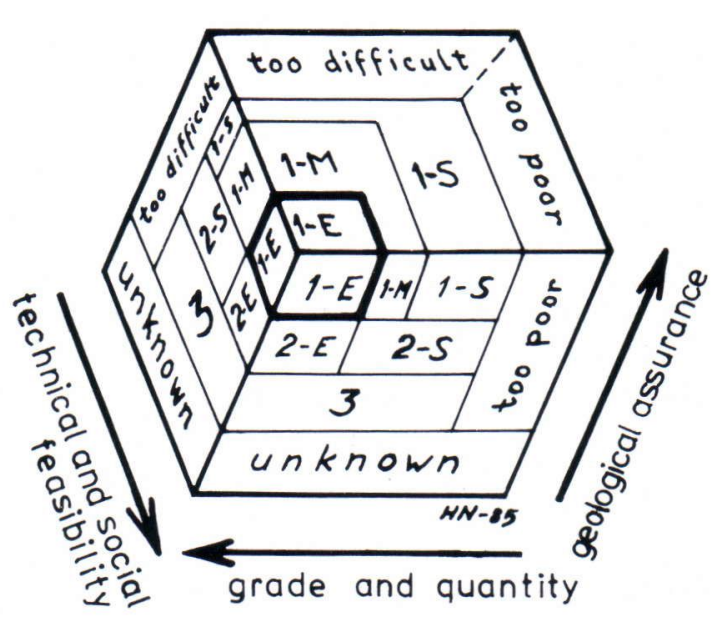

Fig. 2. The U.N. classification of areal mineral resources supplemented by a division of economic interest into two components: (1) grade and quantity (geological features), (2) technical and social feasibility.

the target of mineral development.

As the two components of economic interest thus affect differently the feasibility of reaching the target, these components should be differentiated in the basic areal mineral-resource classification. All the categories of resources of this three-dimensional classification are the same as in the U.N. classification; only the occurrences have been divided into additional boxes following either of these components of economic interest. The usefulness of this consideration of the nature of economic interest is that it throws light on the fundamentals of the classification and facilitates the choice of appropriate development measures for individual occurrences. This is particularly important in Finland, where there are only a small number (some dozens) of factual resource deposits but a relatively large number (many thousands) of occurrences or ore showings (cf. Mikkola and Niini 1968, Puustinen 1980).

In Finland, ore-resource classifications and inventories are naturally being compiled continuously by each mining company. But these compilations are not public and they are only made for deposits of a certain type belonging to, or somehow interesting, the company in question. In addition, a number of inventories of the min- 


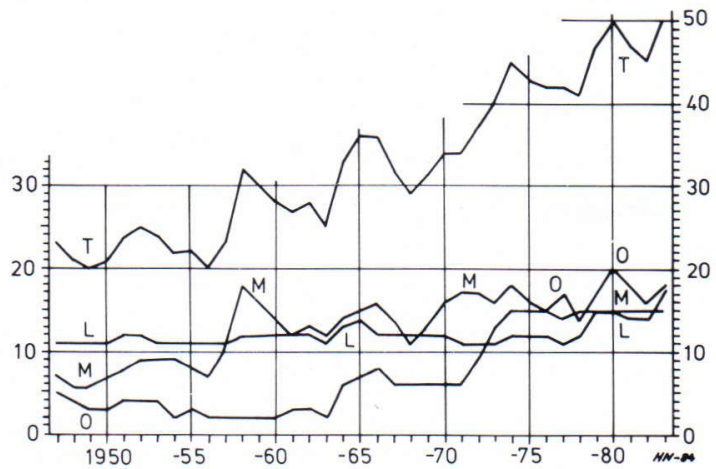

Fig. 3. The number of mines in Finland from 1947 to 1983 (excluding the exploitation of building stones, lake ores, and placer gold) according to the statistics of the Ministry of Trade and Industry (Vuoriteollisuus 1948-1984). Key: $\mathrm{M}=$ metalliferous ores, $\mathrm{L}=$ limestone, $\mathrm{O}=$ other industrial minerals, $\mathrm{T}=$ total number of mines.

eral resources in limited areas of special interest have been made by individual explorationists, e.g. from the Kotalahti-Hitura nickel belt (Gaál et al. 1978), the Vihanti zinc-copper ore zone (Tontti et al. 1981), and central Finnish Lapland (Gaál 1984). But a comprehensive areal inventory of all the mineral resources in Finland classified according to the level of geological assurance and the different factors of economic interest still awaits its author. As the assurance of geological knowledge continues to increase, the work would be a permanent and comprehensive national task requiring a close amalgamation of geology with mining and metallurgical technology and mathematical statistics (cf. Labowitz and Griffiths 1982).

In order to illustrate the quantity of Finnish economic ore resources, the annual number of Finnish deposits belonging to category R-1-E (economically exploitable) is shown in Fig. 3. The total number of R-1-E deposits, which was 50 in 1983 , seems to be increasing gradually.

\section{Development of bedrock resources}

The development of bedrock resources in Finland has three different components: (1) the his- torical development of the concept »bedrock resources», (2) the development in time of the amount and quality of the resources, and (3) the research and development necessary for (future) exploitation of the resources.

\section{Development of the concept "bedrock resources»}

It is obvious that in the past the concept »bedrock resources» was confined to mineral exploitation. In Finland, it was only in the 1960s that people began more generally to regard the bedrock as a resource for other activities, too. It was at this time that the extraction of groundwater from the bedrock through drilled wells became common in Finland (Laakso 1966). The bedrock as a resource for underground space became topical in the 1960s with the planning and realization of a number of large-scale excavation projects, e.g. the many oil-storage caverns in or near densely populated areas and the $120-\mathrm{km}$ long Päijänne-Helsinki water tunnel - the world's longest tunnel in crystalline bedrock (Niini 1968, 1982). The rock environment did not start to interest the public at large until the early 1980s after the four Finnish nuclear power plants had gone on stream and started to produce radioactive waste. Nevertheless, the most important component of the concept »resource» with reference to Finnish bedrock still consists of the mineral resources, which are currently being exploited in 50 mines. Another kind of expansion of the concept »mineral resource» is indicated by the increasing interest shown in old tailings as sources of certain mineral commodities.

\section{Development of the amount of different bedrock resources}

The development of the amount of the bedrock resources can only be described with respect to the various resource types. In principle, all types are limited quantitatively but in a different manner. 
Bedrock resources for underground spaces and rock environments are very large, comprising almost the whole volume formed by the area of Finland down to a depth that can be reached economically. Similarly, the area of the bedrock available as a base for construction is almost directly comparable with the area of the whole country. These resources are finite but extensive and permanent: they cannot be essentially exhausted in time.

Bedrock-groundwater resources are also finite but, unlike the other types of bedrock resources, they are renewable: the amount depends on the catchment area and precipitation; the latter may naturally change in time whereas the former only artificially.

Mineral resources are the only bedrock resources that are completely unrenewable and exhaustible. It is chiefly this characteristic that makes the research and development of mineral resources so important for the future of mankind. However, as explained earlier, the exploitation of a certain mineral resource does not automatically mean a prompt reduction of this resource. Many factors are working in the opposite direction to augment the amount of economic mineral resources. It is of course true that ultimately an end will come to the increase in the total resources of each mineral commodity. A diagram of the remaining resources is presented (Fig. 4) to demonstrate that, for the ordinary mineral ores, this end is not likely in the immediate future.

The historical development of Finnish mineral resources in time is depicted roughly in Fig. 3: A sudden increase in the economic resources of metalliferous ores took place at the end of the 1950s. The economically exploitable resources of limestone (incl. marble and dolomite) are much larger than is reflected by the relatively stable number of limestone mines, which remained at roughly the same level until the end of the 1970s, when there was a slight rise. The resources of other industrial minerals (at the beginning mainly asbestos and talc) were small until the second half

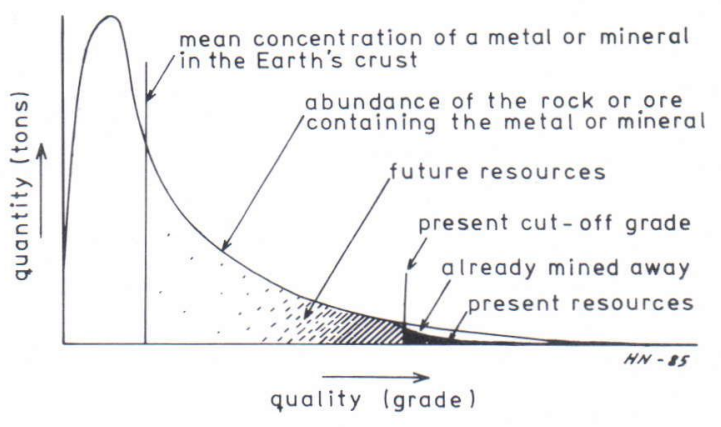

Fig. 4. Schematic presentation of the total remaining mineral resources: the quantity of the resources increases as the cut-off decreases because of continuous mining.

of the 1960s, when a promising gradual upward trend led to the present use of diversified mineral commodities such as quartz, feldspars, pyrite, wollastonite, chromite, ilmenite, $\mathrm{Fe}-\mathrm{Mg}-\mathrm{Al}$ silicates, kaolin, apatite, barite, and phlogopite.

All in all, the total mineral ore resources of Finland have thus tended to increase, becoming step by step more and more diversified. This continuous increase in economic resources is well reflected by the continuous growth in the total output of Finnish mines, which from less than two million metric tons in 1947 accelerated to more than 20 million metric tons in 1983 (Vuoriteollisuus 1948-1984).

\section{Conclusion: Research and development work on bedrock resources}

When searching for new mineral resources, it is important that we first try to forecast what commodities mankind will need in the future, say, after the year 2000. This is unavoidably an arbitrary task, since it is absolutely certain that the variety, amounts, and production localities of mineral commodities will not be the same in 2000 as they are now. The unavoidable exhaustion of the richest deposits and those easiest to exploit will lead to stepwise impairment of the conditions or the quality, or both, of the material adequate for mining. At the same time, 


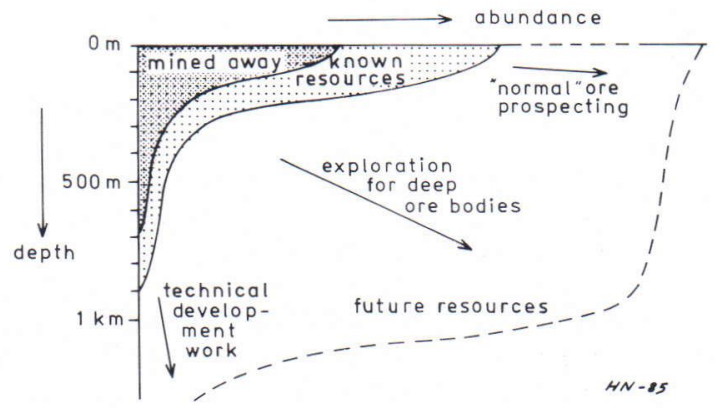

Fig. 5. A simplified scheme of the abundance of ore resources at different depths and the future results of research and development of mineral resources.

however, this fact points the way to new possibilities in mineral exploration. Accordingly, and to conclude on an optimistic note, I have tried to present a scheme of the future results of research and development of mineral resources (Fig. 5). My aim is to illustrate as clearly as possible that active research and development (at all stages of mineral processing and exploration) will sooner or later be profitable.

Finally, let us note that the utilization or development of bedrock resources - the main topic

\section{References}

Banfield, Armine F. \& Havard, John F., 1975. Let's define our terms in mineral valuation. Min. Eng., July 1975, 74-78.

Fettweis, Günter B., 1981. Die internationale Einordnung von Mineralvorräten »The international classification of mineral resources» der Vereinten Nationen. Entstehung und Struktur (I). Erzmetall 34, Nr. 7/8, 400-406.

Gaál, Gabor, 1984. Evaluation of the mineral resource potential of central Finnish Lapland by statistical analysis of geological, geochemical and geophysical data. Geol. Surv. Finland, Rep. Invest. 63, 69 p.

-; Koistinen, E.; Lehtonen, M. \& Tontti, M., 1978. Deposit modeling of a nickel belt in Finland. Math. Geol. Vol. 10, No. 5, 543-554.

Gocht, Werner, 1983. Wirtschaftsgeologie und Rohstoffpolitik. 2nd edition. Springer-Verlag, Berlin. 295 p.

Järvimäki, P. \& Puranen, M., 1979. Heat flow measurements in Finland. P. 172-178 in »Terrestrial Heat Flow in in economic geology - has rapidly become an extremely complex activity. Analysis of the concept of bedrock resources showed that the nature, amount, and location of the individual bedrock resources are closely dependent on excavation and processing technology and on the general trends and changing of human society; they are only partly dependent on geological factors alone. This offers economic geology a serious challenge. The new requirements can be met only by continuous redeployment of research problems and targets and by effective development of methods of research, processing, and utilization of changing bedrock resources. Sometimes the different interests concerned with bedrock resources come into conflict, especially in densely populated areas. Then the optimum solution for utilizing bedrock resources should be reached by making a »regional bedrock plan», i.e. by longterm adjustment of the different interests.

Acknowledgements. Many thanks to my colleagues, Professor Jouko Talvitie and Mr. Runar Blomqvist, Lic. Tech., for offering helpful advice in their reviews of the manuscript, and to Mrs. Gillian Häkli for checking and correcting the English of my draft.

Europe» Ed. V. ̌̌ermák and L. Rybach. SpringerVerlag, Berlin-Heidelberg.

KMP $=$ Kalliomekaniikan päivät (The Finnish Symposia of Rock Mechanics) 1967-1984, 17 vols. The Finnish National Committee for Rock Mechanics, Helsinki.

Laakso, Martti, 1966. Kalliokaivojen veden laatu. Summary: The quality of water in rock wells. Vesitalous 3, 26-30.

Labowitz, M. L. \& Griffiths, J. C., 1982. An inventory of undiscovered Canadian mineral resources. Econ. Geol. 77: 7, 1642-1654.

Mikkola, Aimo K. \& Niini, Heikki, 1968. Structural position of ore-bearing areas in Finland. Bull. Geol. Soc. Finland 40, 17-33.

Niini, Heikki, 1968. A study of rock fracturing in valleys of Precambrian bedrock. Fennia 97: 6, 60 p. Also Papers Eng.-Geol. Soc. Finland Vol. 3.

—, 1982. Päijänne-tunnelin linjauksen ja louhinnan geologiset perusteet. Summary: Water tunnel Päijänne-Helsinki and its geological prerequisites. Rakennustekniikka 38: $8,499-503$. 
Puustinen, Kauko, 1980. Tuloksekas malminetsintä Suomessa. Summary: Results of mineral exploration in Finland. Geologi 32: 9-10, 119-121.

Ritola, Jouko, 1983. Kalliotilojen energiatalous ja lämmön varastointi kallioon. English abstract: Energy economy of underground spaces and heat storage in bedrock. Technical Research Centre of Finland, VTT Research Notes 216. Espoo, 97 p.

Roinisto, J. (editor), 1985. Kalliorakentaminen. Maanalaisten tilojen rakentamisyhdistys r.y. (Rock engineering in Finland. Finnish Tunnelling Association). To be published.

Rönkä, Esa, 1983. Drilled wells and ground water in the Precambrian crystalline bedrock of Finland. Publ. Water Res. Inst. (Finland) 52, $57 \mathrm{p}$.

Tontti, M.; Koistinen, E. \& Seppänen, H., 1981. Vihannin Zn-Cu-malmivyöhykkeen geomatemaattinen arviointi. Summary: Geomathematical evaluation of the Vihanti Zn$\mathrm{Cu}$ ore zone. Geological Survey of Finland, Report of Investigation No. 54,58 p.

Tyni, Matti, 1981. Malmin määritelmästä (On the definition of ore; in Finnish). Geologi 6, 83-85.

$U N=$ United Nations Committee on Natural Resources, 1979. The international classification of mineral resources. Session report, 6. Session, 5.-15. 6. 1979, New York. USBM-USGS 1976 = Principles of the mineral resource classification system of the U.S. Bureau of Mines and U.S. Geological Survey. U.S. Geol. Surv. Bull. 1450-A, p. A1-A5.

Virtanen, Erkki, 1982. Louhintamäärien kehitys (The development of the amounts of blasted rock; in Finnish). Kalliomekaniikan päivä 1982, II, 18 p. Suomen Geoteknillinen Yhdistys.

Vuorela, Paavo \& Äikäs Timo, 1984. Site selection studies for final disposal of spent fuel in Finland. Geol. Surv. Finland, Nuclear Waste Disposal Research, Rep. 39, 15 p.

Vuoriteollisuus 1948-1984 = The statistics of the Ministry of Trade and Industry concerning the Finnish mining industry. Vuoriteollisuus - Bergshanteringen, vols 1948 - 1984. The Mining and Metallurgical Society of Finland. 